\title{
Production of In Vitro Diagnostics
}

National Cancer Institute

\section{Source}

National Cancer Institute. Production of In Vitro Diagnostics. NCI Thesaurus. Code

C113049.

The production an in vitro testing system or kit to detect viral or bacterial agents in donor blood. 